\title{
Teogonia e Anti-Édipo: uma aproximação
}

\author{
HENRIQUE ZANELATO
}

Notamos, ao longo da leitura de alguns capítulos d' $O$ anti-Édipo, bem como dos seminários e discussões realizados ao longo da disciplina ${ }^{2}$, como Deleuze e Guattari argumentam sobre o modo como a sociedade se desenvolveu e se organizou ao longo dos séculos. Sua análise remonta às formas de organização sociais mais primordiais, partindo do que chamaram de socius primitivo ou selvagem, passando pelo bárbaro, até alcançar o civilizado. Deve-se salientar, no entanto, que os autores não consideram essa passagem como um processo por meio do qual um socius nada possui do outro, já que podem haver aspectos de um deles no outro, ou que as sociedades se desenvolveram nessa relação com os socius ao mesmo tempo. Queremos, com o presente trabalho, fazer uma espécie de analogia entre esse processo e uma leitura sobre a mitologia grega, dando atenção especial, sobretudo, ao socius civilizado e o seu caráter axiomatizador. É preciso dizer, no entanto, que é possível que essa analogia não consiga ser levada às últimas consequências, no sentido de dizer que mitologia e anti-Édipo sejam totalmente correspondentes. Pretendemos, assim, apenas aproximar alguns aspectos entre os textos, mostrando possíveis pontos de ligação.

A tradição da mitologia grega, legada em boa parte por Hesíodo, registrou o surgimento de tudo, desde os deuses até os fenômenos naturais e os homens, a partir de um conjunto primordial: segundo a Teogonia, "[...] bem primeiro nasceu Caos, depois também Terra de amplo seio, de todos sede irresvalável sempre [...], e Tártaro nevoento no fundo do chão de amplas vias, e Eros: o mais belo entre Deuses imortais" (Teogonia, vv. 116-121). O ponto que queremos aproximar, aqui, é o caráter dado para a Terra, também chamada de Gaia. Ela é relacionada, na mitologia grega, com a fertilidade, e também com abrigo, com lar. Poucas entidades foram geradas fora de sua linhagem, mas todos residem em seu "amplo seio". Deleuze e Guattari, ao falarem sobre a máquina territorial primitiva, colocam o corpo pleno e indivisível da terra como seu princípio.

A unidade primitiva, selvagem, do desejo e da produção é a terra. Porque a terra não é apenas o objeto múltiplo e dividido do trabalho, mas também a entidade única indivisível, o corpo pleno que se assenta sobre as forças produtivas e delas se apropria como seu pressuposto natural ou divino. O solo pode ser o elemento produtivo e o resultado da apropriação, mas a Terra é a grande estase inengendrada, o elemento superior à produção que condiciona a

\footnotetext{
${ }^{1}$ Graduado em Filosofia pela UNIOESTE (2015) e ex-acadêmico bolsista do PET na mesma instituição. Atualmente cursa mestrado em Filosofia pela UNIOESTE. E-mail: henriquezanelatoii@hotmail.com ${ }^{2}$ A disciplina foi ministrada pela professora Ester Maria Dreher Heuser no primeiro semestre de 2016, tratando da obra O anti-Édipo, de Deleuze e Guattari.
} 
apropriação e a utilização comuns do solo. Ela é a superfície sobre a qual se inscreve todo o processo da produção, sobre a qual são registrados os objetos, os meios e as forças de trabalho, sobre a qual se distribuem os agentes e os produtos (DELEUZE; GUATTARI, 2010, p. 187).

Passando por cima de alguns elementos importantes desse primeiro socius, chamado primitivo, ou selvagem, diremos apenas que os autores consideram toda a sociedade, nesse primeiro estágio, como ligada ao corpo da Terra, tudo o que é feito na aldeia é inscrito nele. Em Hesíodo, a Terra, primeiro, pariu o Céu, ou Urano. Essa primeira geração, feita sem parceiro, trouxe à luz seu parceiro. A partir, então, dessa primeira união com o Céu, a Terra passou a gerar muitos outros filhos, servindo de morada a tudo o que era gerado não só de si, mas de todas as outras uniões.

Dessa união, no entanto, surgiram alguns problemas: "Céu constelado, para cercá-la [Terra] toda ao redor", mostrou-se como um pai tirânico e que, detestando os filhos temíveis que nasciam de sua união com a Terra, tão logo nasciam, eram ocultados dentro da mãe. Do coito com o Céu, surgiram "Oceano de fundos remoinhos e Coios e Crios e Hipérion e Jápeto e Téia e Réia e Têmis e Memória e Febe de áurea coroa e Tétis amorosa. E após com órimas armas Crono de curvo pensar, filho o mais terrível" (vv. 132-139), além dos Ciclopes. Cansada de ter os filhos impedidos de ver a luz pela tirania do parceiro, Terra tramou um plano para vingar-se. Forjando uma "foice dentada", Terra convocou os filhos clamando para que algum deles se levantasse contra o pai. O único que se dispôs ao ato foi Crono: "Mãe, isto eu prometo e cumprirei a obra, porque nefando não me importa o nosso pai, pois ele tramou antes obras indignas" (vv. 170-173).

Escondido para uma armadilha, Crono espera que o pai, "desejando amor", procure a Terra. Quando ele aparece, Crono levanta-se de seu esconderijo, ceifando o pênis do Céu, motivo de toda a sua virilidade. O sangue e o órgão do pai, em contato com a Terra e o Mar, ainda geraram seus últimos filhos. Desse ato ocorre a ascensão de Crono como novo soberano entre os deuses, mas não ocorre o esperado por Terra e seus outros filhos: o Titã de curvo pensar casa-se com a irmã, mas acaba agindo do mesmo modo que seu pai. Tão logo Réia, sua esposa, paria um de seus "brilhantes filhos", Crono o engolia, não deixando que nenhum deles se desenvolvesse, já que seu pai o amaldiçoara dizendo que "castigo teria no porvir". Com medo de perder seu lugar, assim como seu pai perdera para ele, Crono toma os filhos dos braços da irmãesposa e os engole.

Essa passagem nos mostra outro ponto de aproximação com a obra de Deleuze e Guattari. De acordo com eles, a passagem do estado selvagem para o bárbaro se dá exatamente no momento em que a máquina territorial, erigida sobre o corpo da terra, passa para a máquina despótica. As relações não se dão mais sobre o corpo indivisível da terra, mas sobre o corpo de um déspota que transforma todo o modo de viver. Com 
o Céu, mesmo que tenha se portado de modo tirânico, ainda havia a Terra, geradora de vida e sede de toda a vida, mesmo que seus filhos ficassem encarcerados. Agora, no entanto, Terra perde seu papel de geradora e de prisão para os filhos, tendo Crono como o grande déspota que teme perder seu lugar para um de seus próprios filhos, prendendo-os dentro de si.

Outro ponto que permite alguma aproximação é o modo como o déspota surge, impondo o socius bárbaro: Deleuze e Guattari atribuem-lhe uma atividade incestuosa, explicando o modo como transforma todo o sistema de organização social. De acordo com os autores, o déspota modifica os modelos de filiação e aliança cometendo um incesto duplo, com a irmã, alterando o sistema de alianças, e com a mãe, alterando o sistema de filiação, transformando-o em um modelo vertical e hierárquico (DELEUZE; GUATTARI, 2010, p. 265). Mesmo que a ordem seja diferente, já que em Deleuze e Guattari o primeiro incesto seja com a irmã, e que Crono não tenha propriamente se relacionado de modo sexual com a mãe, podemos aproximar sua associação com a Terra como uma espécie de união. Crono se estabelece como tirano, como déspota, a partir da união com sua mãe e com sua irmã.

Crono, no entanto, não contava com a união das duas mulheres que o colocaram em seu lugar para uma nova armadilha. Sofrendo por ter seus filhos engolidos, assim como sua mãe, Réia clama a ajuda de seus pais para "comporem um ardil para que oculta parisse o filho, e fosse punido pelas Erínias do pai e filhos engolidos o grande Crono de curvo pensar" (vv. 471-473). Eis que Réia foge para uma região distante de seu marido, para que pudesse dar à luz Zeus, o último filho de Crono. Ao exigir o filho para que tivesse o mesmo destino dos outros, o tirano recebe de Réia uma grande pedra, enrolada em alguns mantos. $\mathrm{O}$ deus a devora sem nem perceber o embuste. Zeus, protegido, crescia longe dali criado e nutrido por Ninfas: "rápido o vigor e os brilhantes membros do príncipe cresciam. E com o girar do ano, enganado por repetidas instigações da Terra, soltou a prole o grande Crono de curvo pensar, vencido pelas artes e violência do filho" (vv. 493-496). Enganado, Crono acaba por vomitar todos os filhos engolidos, que se unem a Zeus para uma batalha contra o pai. Além disso, Zeus liberta alguns dos outros filhos da Terra e do Céu, que continuavam presos, contando, também, com a ajuda destes.

Zeus sai vencedor dessa batalha e temos a última grande mudança na mitologia. Ao tomar o lugar do pai, Zeus é alertado de que tem que tomar algumas providências, para que não tenha o mesmo destino do pai e do avô. Para que não fosse enganado, foi aconselhado a desposar, primeiro, não uma irmã, como Crono, mas outra divindade, conhecida como Astúcia, ou Métis. Terra e Céu o aconselham que Zeus a engula, para que tome para si toda a personificação da astúcia, de modo que esteja sempre um passo à frente de qualquer trama que lhe possa ameaçar o poder, e para que nenhum dos filhos desse casamento o destrone. Tal ato é o que garante toda a perenidade do governo de Zeus sobre os deuses e sobre os homens. 
O ponto para o qual queremos chamar atenção sobre Zeus é o seu caráter vingativo, ou punitivo, em relação a todos aqueles que tentaram lhe enganar. Um desses foi o famoso Prometeu. Prometeu é conhecido por ter enganado Zeus duas vezes: uma história diz respeito ao roubo do fogo, e essa história traz diferentes versões. Fiquemos com a contada por Sócrates, no Teeteto (PLATÃO, 2001). Segundo ele, Prometeu e seu irmão, Epimeteu, ficaram encarregados da criação dos animais e dos homens. Eis que Epimeteu faz o trabalho, distribuindo garras e dentes afiados, grossas camadas de couro, pelos e escamas entre todos os animais. Quando chegou a vez do homem, não restava nenhuma arma para que esse pudesse se defender e proliferar. Prometeu, então, para ajudar os homens sobe ao Olimpo e rouba o fogo dos deuses. A outra história diz respeito a certa ocasião onde o rei dos deuses foi convocado a escolher o sacrifício que os homens deveriam fazer em honra aos deuses. O embuste acontece porque Prometeu esconde a carne de um boi dentro de seu intestino, e os ossos envoltos em "brilhante banha". Zeus, enojado com a aparência do intestino do boi, escolhe o conteúdo coberto pela gordura e fica furioso ao encontrar apenas os ossos do animal. A escolha faz com que a parte da carne fique reservada aos homens, enquanto os sacrifícios aos deuses sejam feitos com os ossos.

Dois castigos são tirados dessas histórias: Zeus, irado, pune os homens com a primeira mulher, Pandora, que, por sua curiosidade, acaba por abrir uma caixa onde se depositavam todos os males, deixando-os escapar sobre o mundo; o outro é um castigo dado diretamente a Prometeu. Acorrentado nas encostas de uma montanha, Zeus envia uma águia para comer parte de seu fígado durante o dia. A pior parte do tormento era que esse castigo se tornava infinito, visto que, toda noite, a parte comida de seu fígado se regenerava, repondo o alimento da ave. $\mathrm{O}$ término de seu tormento só se deu quando Héracles, com a permissão de Zeus, o liberta de suas correntes. Vemos alguns outros exemplos de castigos impostos pelo deus a diversos personagens da mitologia, como a Atlas, por exemplo, condenado a segurar o céu sobre os ombros durante toda a eternidade.

Em Deleuze e Guattari, a última transformação, até então, no socius é a passagem da máquina despótica para a máquina capitalista, constituída pelo socius civilizado. O corpo sobre o qual a sociedade se mantém não é mais o da terra, como entre os selvagens, ou o do déspota, como entre os bárbaros, mas o do capital. Além dessa, temos outra diferença: enquanto no primeiro socius havia uma codificação dos fluxos de desejo, e no segundo havia uma sobrecodificação, o socius civilizado os descodifica: "É que o capitalismo, como vimos, é efetivamente o limite de toda sociedade, uma vez que opera a descodificação dos fluxos que as outras formações sociais codificavam e sobrecodificavam" (DELEUZE; GUATTARI, 2010, p. 326). Esses fluxos descodificados pelo capitalismo, no entanto, sofrem o que se chama de axiomatização, onde a energia desses fluxos é canalizada para o corpo do capital. Há, no entanto, alguns fluxos que tentam "escapar" dessa axiomatização feita pelo socius 
civilizado que, ao invés de se remeterem ao corpo do capital, vão em direção ao que os autores chamam de "corpo sem órgãos". Essa tentativa de fugir da axiomatização capitalista é chamada, por eles, de esquizofrenia. Assim como os fluxos do capital, a esquizofrenia também os têm descodificados. O que difere, porém, é que a esquizofrenia pretende fluxos que não sejam levados ao corpo do capital, pretende fluxos que lhe escapem.

Seguindo nossa analogia, podemos considerar que, em certo modo, se tomarmos a passagem de Crono para Zeus como a passagem do socius bárbaro para o civilizado, é possível fazer certa relação dos embustes de Prometeu com o processo de esquizofrenia. Enquanto este tenta dar certo conforto aos homens, negando ainda mais bens a Zeus, Prometeu procura direcionar a outro lugar certa energia que caberia a Zeus, entendido como o corpo do capital. Não devemos deixar de notar, por outro lado, que o deus, por mais que tenha, por assim dizer, perdido uma batalha, vendo alguns fluxos escaparem, acaba por mostrar seu poder na punição que delega não só a Prometeu, mas também aos homens. Essa punição, parece, pode ser pensada como a axiomatização capitalista, visto que, apesar de dividir o fogo com os homens, este acaba por ser a maneira como os sacrifícios lhe são oferecidos. Além disso, o castigo ainda serve como meio de alerta para qualquer tentativa de escapar à axiomatização, dificultando a execução de qualquer processo que não lhe seja dirigido.

\section{Referências}

DELEUZE, G.; GUATARRI, F. O anti-Édipo: capitalismo e esquizofrenia. Trad. Luiz B. L. Orlandi. São Paulo: editora 34, 2010.

HESÍODO. Teogonia: a origem dos deuses. Trad. Jaa Torrano. São Paulo: ed. Iluminuras, 1995.

PLATÃO. Teeteto. Trad. Carlos Alberto Nunes. Belém: ed. EDUFPA, 2001.

Submissão: 09.05.2017 / Aceite: 15.06.2017 